Article

\title{
Genome Sequence of the Fish Pathogen Yersinia ruckeri SC09 Provides Insights into Niche Adaptation and Pathogenic Mechanism
}

\author{
Tao Liu ${ }^{1,+}{ }^{\dagger}$ Kai-Yu Wang ${ }^{1,2, *,+}{ }^{+}$Jun Wang ${ }^{1,+}{ }^{\dagger}$, De-Fang Chen ${ }^{3}$, Xiao-Li Huang ${ }^{3}$, Ping Ouyang ${ }^{1}$, \\ Yi Geng ${ }^{1}$, Yang $\mathrm{He}^{1}$, Yi Zhou ${ }^{2,3}$ and Jie Min ${ }^{1}$ \\ 1 Department of Basic Veterinary, Veterinary Medicine College, Sichuan Agricultural University, \\ 211 Huimin Road, Chengdu 611134, Sichuan, China; liutao1232123@163.com (T.L.); \\ wangjunzl@126.com (J.W.); ouyangping125@163.com (P.O.); gengyisicau@126.com (Y.G.); \\ he_yang_yang@126.com (Y.H.); minjie00awesome@163.com (J.M.) \\ 2 Key Laboratory of Animal Disease and Human Health of Sichuan Province, Sichuan Agricultural University, \\ Chengdu 611134, Sichuan, China; 13981616210@139.com \\ 3 Department of Aquaculture, College of Animal Science \& Technology, Sichuan Agricultural University, \\ Chengdu 611134, Sichuan, China; chendf_sicau@126.com (D.-F.C.); hxldyq@126.com (X.-L.H.) \\ * Correspondence: kywang1955@126.com; Tel.: +86-28-8629-1301 \\ + These authors contributed equally to this work.
}

Academic Editors: Jun Li and Li Lin

Received: 23 January 2016; Accepted: 5 April 2016; Published: 14 April 2016

\begin{abstract}
Yersinia ruckeri is the etiologic agent of enteric red mouth disease (ERM), a severe fish disease prevailing in worldwide aquaculture industries. Here we report for the first time the complete genome of Y. ruckeri (Yersinia ruckeri) SC09, a highly virulent strain isolated from Ictalurus punctatus with severe septicemia. SC09 possesses a single chromosome of 3,923,491 base pairs, which contains 3651 predicted protein coding sequences (CDS), 19 rRNA genes, and 79 tRNA genes. Among the CDS, we have identified a Ysa locus containing genes encoding all the components of a type III secretion system (T3SS). Comparative analysis suggest that SC09-Ysa share extensive similarity in sequence, gene content, and gene arrangement with Salmonella enterica pathogenicity island 1 (SPI1) and chromosome-encoded T3SS from Yersinia enterocolitica biotype 1B. Furthermore, phylogenetic analysis shown that SC09-Ysa and SPI1-T3SS belong on the same branch of the phylogenetic tree. These results suggest that SC09-Ysa and SPI1-T3SS appear to mediate biological function to adapt to specific hosts with a similar niche, and both of them are likely to facilitate the development of an intracellular niche. In addition, our analysis also indicated that a substantial part of the SC09 genome might contribute to adaption in the intestinal microenvironment, including a number of proteins associated with aerobic or anaerobic respiration, signal transduction, and various stress reactions. Genomic analysis of the bacterium offered insights into the pathogenic mechanism associated with intracellular infection and intestinal survivability, which constitutes an important first step in understanding the pathogenesis of Y. ruckeri.
\end{abstract}

Keywords: Yersinia ruckeri; whole-genome sequencing; type III secretion system; niche adaptation; pathogenicity

\section{Introduction}

Yersinia ruckeri, a Gram-negative rod-shaped bacterium, is the etiological agent for enteric red mouth disease (ERM) in various fish species, resulting in severe economic losses in aquaculture [1]. The organism was isolated from salmonid fish with ERM in the United States as early as the 1950s [2]. Subsequently, in the late 1970s to the 1980s, it was introduced to Europe from the USA [3-6]. Since then, 
the hosts and geographic distribution of this pathogen has increased. Now, it has been isolated in many countries around the world and spread throughout North and South America, Europe, Australia, South Africa, the Middle East, and China, ranging from different hosts such as rainbow trout, carp, catfish, sturgeon, burbot, and perch [1,2]. Vaccination is the most effective method of combating disease and the first commercially available fish vaccine was an immersion vaccine against ERM [7]. Often vaccination by injection is the most effective means of disease prevention in aquaculture. However, this method is stressful for the fish and labor intensive for the farmer. So, novel oral and immersion delivery methods have captured the attention of researchers and aquarists and some corresponding fish vaccines have been developed [8]. Despite the general administration of a quite effective immersion vaccine in salmonid fish, outbreaks still occur, produced mainly by certain isolates [9-11]. These nonmotile isolates were different from previous strains, and they were classified as Y. ruckeri biotype $2[12,13]$. Recently, it is one of the most important infectious diseases in Ictalurus punctatus aquaculture in China [14].

ERM caused by Y. ruckeri is a serious septicemic disease [1]. Pathological changes in diseased Ictalurus punctatus shows general septicemia with inflammation in most organs, including the kidney, spleen, liver, and gastrointestinal tract (Figure 1). The pathogenic mechanisms of Y. ruckeri may be associated with its characterization of intracellular infection and intestinal infection. In the process of infection, the organism may invade the gill epithelium and gastrointestinal tract epithelium in the early phase and then enter the blood circulatory system in the later phase, after which it could further infect the spleen and trunk kidney, and accumulate in the lymphoid organs, finally breaking down the immune system [15]. Studies have also shown that $Y$. ruckeri is a facultative intracellular pathogen; it could survive inside macrophages in vitro as well as in vivo and the number of bacteria inside macrophages steadily increased after immersion infection [16]. The molecular basis of intracellular survival and extracellular intestinal survival on Y. ruckeri are still unclear, although both contribute to pathogenicity in fish. In fact, studies into the pathogenic characterization of Y. ruckeri are still limited presently, as most researchers' efforts have focused on individual virulence factors, such as extracellular toxins, high affinity iron uptake system, and resistance to innate immune mechanisms [17-25]; systemic research is lacking. In addition, the genetic background of $Y$. ruckeri is still unclear, although some genome sequences of $Y$. ruckeri isolated from salmonid fish have been uploaded onto NCBI [26-28]. So, for the purposes of systematic research into $Y$. ruckeri, we utilized second-generation sequencing (SGS) technologies to obtain the complete genome sequence of biotype 1 Y. ruckeri SC09 isolated from Ictalurus punctatus in Jianyang, China [29]. The genomic analysis provided insights into the niche adaptation of $Y$. ruckeri and countered the blind spots and limitations to our knowledge of the patterns of virulence evolution in Yersinia.

\section{Results and Discussion}

\subsection{Overview of SC09 Genome Sequence}

We used the Illumina Hiseq2000/Miseq Sequencing platform to yield $3002 \mathrm{Mb}$ paired-end reads (Table S2; Figure S1) that were assembled into 32 contigs (>200 bp) and seven scaffolds (N50 = 3,125,824 bp, Table S3), giving 769-fold coverage of the genome (Figure S2). The seven scaffolds were assembled into a single 3,923,491 bp circular chromosome based on their size (Figure 2). We can clearly observe the GC-skew change at the origin and terminus of replication (oriC), where the leading strand and the lagging strand exchange with each other. However, an obvious region in which GC skew + changed to GC skew- has occurred at the left side of the oriC, which may be a mark of lateral genetic transfer (LGT) events in the bacterial chromosomes. The general features of the $Y$. ruckeri $\mathrm{SC} 09$ genome are summarized in Table 1. This organism contains a 3.9-Mb chromosome with an average GC content of $47.45 \%$, which is the largest genome in all sequenced Yersinia ruckeri on NCBI. The coding region accounts for $84.29 \%$ of the chromosome and is composed of 3651 coding sequences (CDS), and the gene length most focused on had 100-1400 bp (Table 1; Figure S3). A total of 79 tRNA 
genes, 19 rRNA genes, representing all 20 amino acids, and 29 sRNA genes were found in the genome. The repetitive DNA sequences in SC09 have been shown in Tables 2 and 3 (Table S4-S7), which can be used in molecular typing.

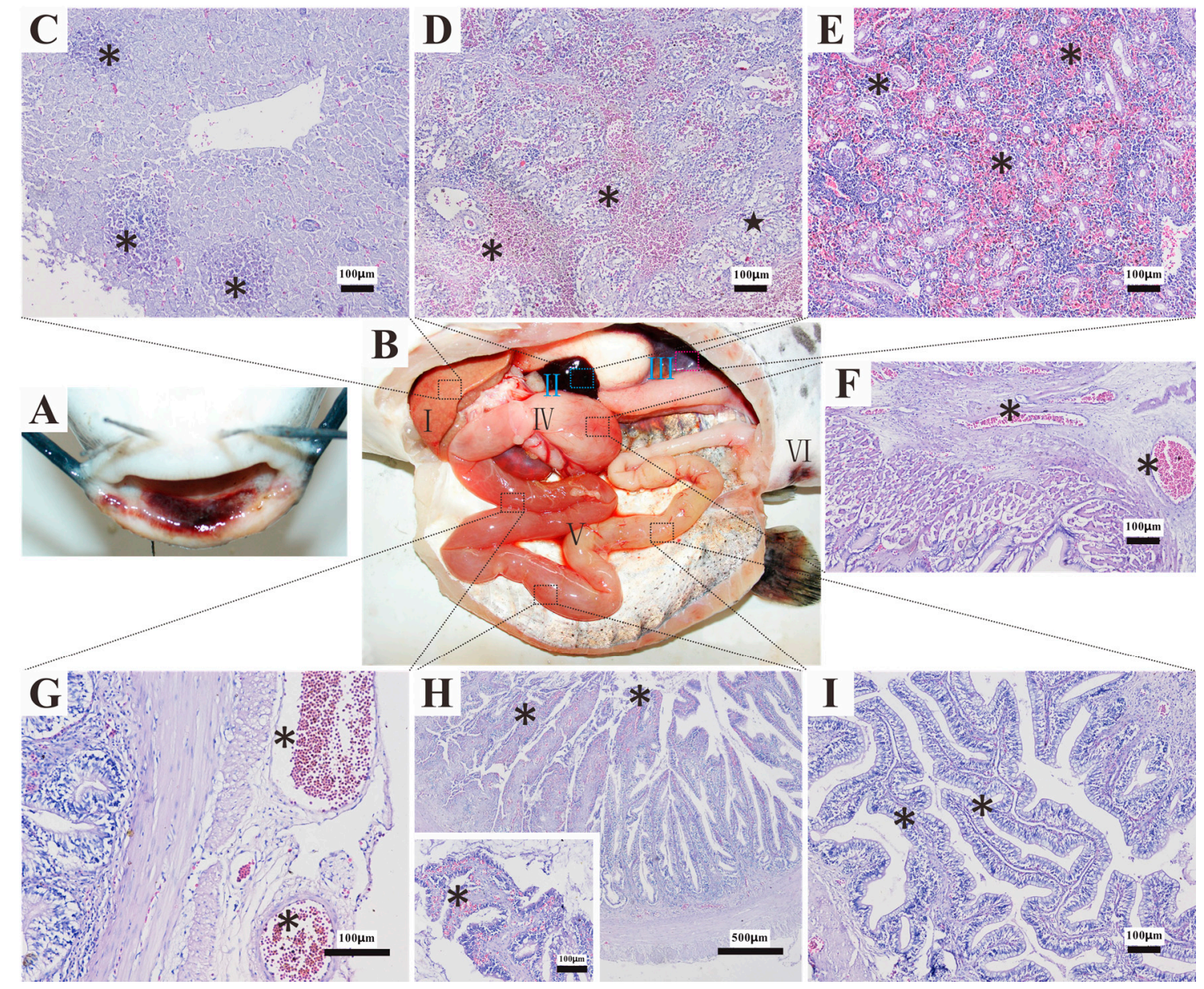

Figure 1. Main symptoms and histopathological changes of the diseased Ictalurus punctatus. (A) Mandibular hemorrhage in Ictalurus punctatus infected with Y. ruckeri; (B) enlarged liver (I), black spleen (II), nephremia (III) and reddened intestine and anus (IV, V, VI); (C) liver coagulation necrosis, necrosis area $(*)$; (D) spleen hemorrhage $(*)$ and edema $(\star)$; (E) renal interstitium hemorrhage $\left(^{*}\right)$; (F) mucosa and serosa of stomach hyperemia $\left({ }^{*}\right) ;(\mathbf{G})$ intestinal serosa hyperemia $\left({ }^{*}\right)$; $(\mathbf{H})$ intestinal epithelial cell causing severe necrosis and fall off, intestinal mucosa hemorrhage $\left({ }^{*}\right)$; (I) Intestinal villus hyperplasia $\left({ }^{*}\right)$.

Table 1. General features of the genome of Y. ruckeri SC09.

\begin{tabular}{cc}
\hline Category & Characteristics \\
\hline Genome size $(\mathrm{bp})$ & $3,923,491$ \\
GC content $(\%)$ & 47.45 \\
Gene number & 3651 \\
Gene total length $(\mathrm{bp})$ & $3,307,170$ \\
Gene average length $(\mathrm{bp})$ & 906 \\
Gene length/Genome $(\%)$ & 84.29 \\
tRNA & 79 \\
rRNA & $8 \times 5 \mathrm{~s}, 5 \times 16 \mathrm{~s}, 6 \times 23 \mathrm{~s}$ \\
sRNA & 29 \\
\hline
\end{tabular}




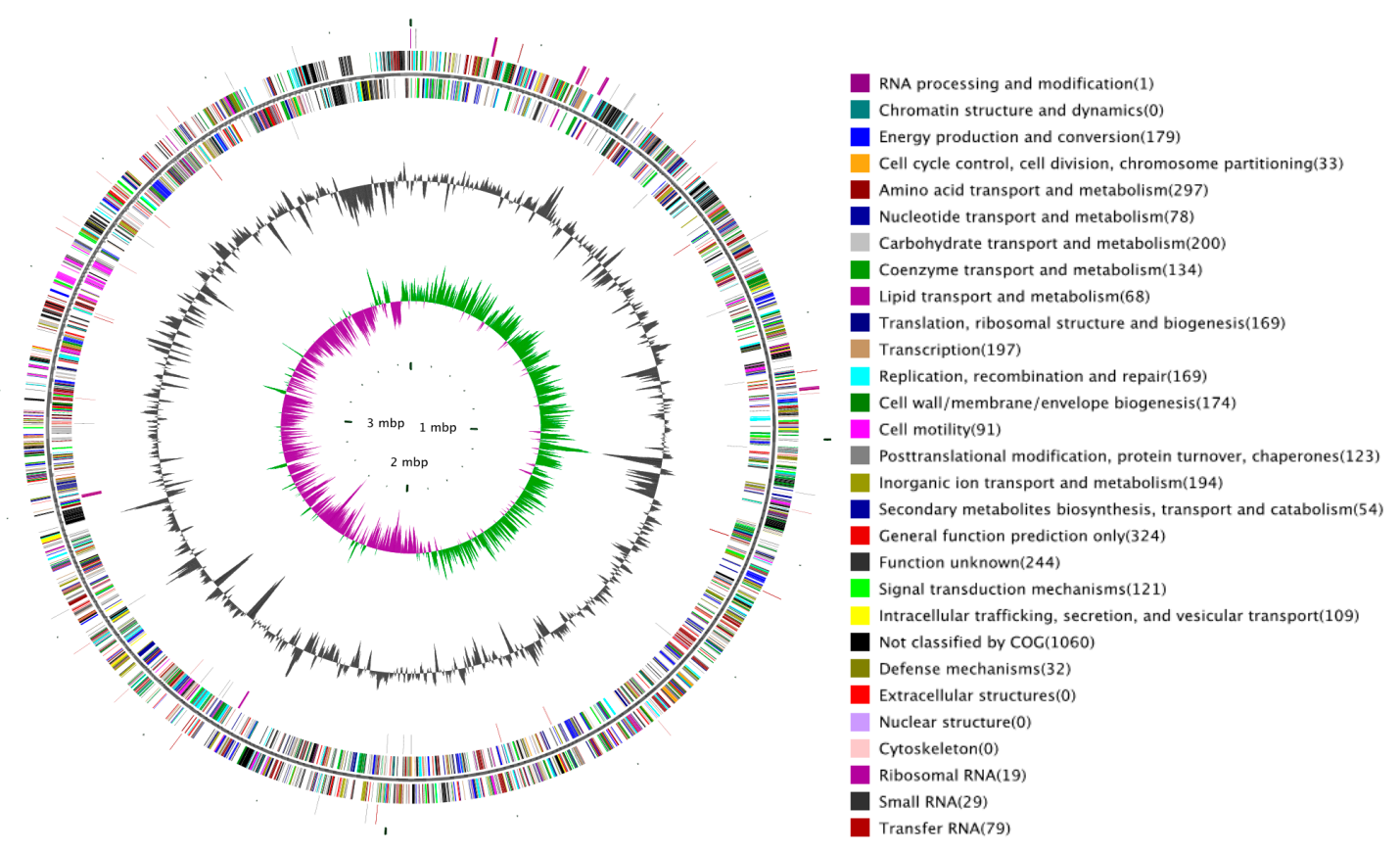

Figure 2. Genome map of Yersinia ruckeri SC09. Starting from the outermost ring and moving inwards, the rings show the location of (1) noncoding RNA on the leading strand; (2) all annotated CDS on the leading strand (colors indicating the assigned COG classes); (3) all annotated CDS on the lagging strand (colors indicating the assigned COG classes); (4) noncoding RNA on the leading strand; (5) The two innermost rings show the GC content (black), GC skew+ (green), and GC skew-(dark purple). The legend at the right explains the colors used to indicate the functional COG groups (Figure S4).

Table 2. Information of interspersed repetitive sequences.

\begin{tabular}{ccccc}
\hline Repeat Class & Number & Total Length (bp) & In Genome (\%) & Average Length (bp) \\
\hline LTR & 79 & 6640 & 0.1692 & 84 \\
DNA & 20 & 1270 & 0.0324 & 64 \\
LINE & 24 & 1786 & 0.0455 & 74 \\
SINE & 10 & 711 & 0.0181 & 71 \\
RC & 1 & 37 & 0.0009 & 37 \\
scRNA & 0 & 0 & 0 & 0 \\
Unknown & 3 & 253 & 0.0064 & 84 \\
Total & 137 & 10,565 & 0.2693 & 78 \\
\hline
\end{tabular}

LTR = long terminal repeat sequence; DNA = DNA transposon; LINE = long interspersed repeated sequence; SINE $=$ short interspersed repeated sequence; $\mathrm{RC}=$ rolling circle; $\mathrm{scRNA}=$ small cytosolRNA .

Table 3. Information of tandem repetitive sequences.

\begin{tabular}{ccccc}
\hline Type & Number & Repeat Size (bp) & Total Length (bp) & In Genome (\%) \\
\hline TRF & 212 & $5 \sim 400$ & 23,928 & 0.6099 \\
Minisatellite DNA & 122 & $11 \sim 58$ & 3694 & 0.0942 \\
Microsatellite DNA & 22 & $5 \sim 6$ & 565 & 0.0144 \\
\hline \multicolumn{5}{c}{ TRF = tandem repeat sequence. }
\end{tabular}

\subsection{Type III Secretion System (T3SS) and Type II Secretion System (T2SS)}

These days, one of the most interesting findings related to bacterial pathogenesis is the discovery that many pathogens utilize some complex mechanisms to deliver toxins into target eukaryotic cells [30]. These toxins can modulate various cellular functions that are of benefit to the pathogen [31]. The type 
III secretion system (T3SS) belongs to these protein-delivery machines. T3SSs, as macromolecular nanomachines, are widespread in many Gram-negative bacteria, which involve over 20 different proteins [31]. Among different bacterial species, the overall architecture of T3SSs is similar, but T3SS-encoding operons and the genes encoding for individual components often present a different organizational profile, with the most notable distinctions being identified for genes involved in the regulatory cascade [32]. Often T3SS are found on virulence plasmids, but several systems are dispersed around the chromosome [33]. A T3SS-encoding operon (NJ56_03735- NJ56_03895) was identified from the chromosome in Y. ruckeri SC09 and named Ysa (red, Figure 3). The SC09-Ysa is located between 829,763 and 862,347 bps and is located closest to the conserved gene mutS (orange, NJ56_03725, encoding DNA mismatch repair protein), associated with the integration of this element into this site, which is similar to SPI1-T3SS (salmonella pathogenicity island 1) [34]. SPI1 is a 40-kb locus encoding a type III secretion system, and acts as a major virulence determinant of Salmonella enterica [35]. In the process of infection for S. enterica, SPI1 primarily contributes to the invasion of non-phagocytic enterocytes and mediates the inflammatory responses of the intestines [36]. This island also plays a key role in the survival and persistence of bacteria within the systemic compartment of the host [37].

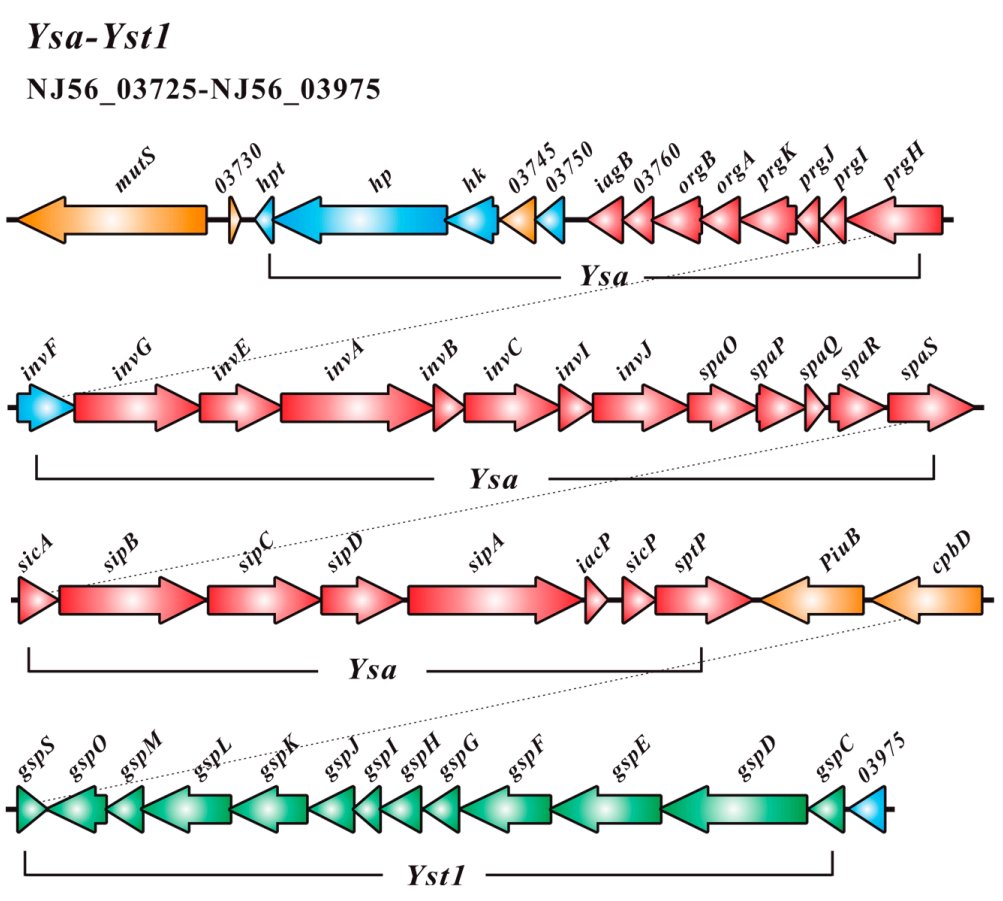

Figure 3. Gene clusters associated with type III secretion system Ysa and type II secretion system Yst1 in SC09.

The core component of the T3SS is the needle complex, a multi-ring structure that spans the bacterial envelope [38]. Structural organization of the nanomachines is involved in the base, needle, inner membrane export apparatus, cytosolic components, needle tip, and translocon [39]. In SC09-T3SS, the invG, prgH, and prgK (NJ56_03800, NJ56_03790, and NJ56_03775, respectively) encodes the base, which is composed of two rings associated with the inner membrane (encoded by $\mathrm{prgH}$ and $\mathrm{prgK}$ ) and an outer membrane (encoded by inv $G$ ). Tertiary structure prediction of these three protein-encoding genes indicated that they all share a small domain with an $\alpha \beta \beta \alpha \beta$ configuration (Figure S5); such a domain may be responsible for ring formation [40]. prgI (NJ56_03785) and prgJ (NJ56_03780) are predicted to encode the needle substructure, assembled from multiple copies of a single residue subunit, and in silico modeling has shown that these two proteins share a similar $\alpha$-helical hairpin shape flanked by flexible regions (Figure S5). Inner membrane export apparatus are encoded by 
invA (NJ56_03810), spaP (NJ56_03840), spaQ (NJ56_03845), spaR (NJ56_03850), and spaS (NJ56_03855), which were predicted as channels to transport effectors through the inner membrane [30]. There are several cytosolic proteins that are also essential for the initial secretion of the effectors and they are conserved compared with other components across all T3SSs: an ATPase (InvC), a stalk that links the ATPase to the plasma membrane (InvI), a ring-like component that may act as a sorting platform for ATPase (SpaO), a stator that can recruit the ATPase to the ring-like component (OrgB), and an additional accessory protein (OrgA) [38]; they are respectively encoded by invC, invI, spaO, $\operatorname{org} B$, and $\operatorname{org} A$ (NJ56_03820, NJ56_03825, NJ56_03835, NJ56_03765, and NJ56_03770) in SC09-Ysa, of which the ATPase could unfold some effector proteins in vitro, and therefore may play an equivalent role in vivo [41]. The needle filament is capped at its tip by a single protein [42] and the tip protein is encoded by sipD (NJ56_03875) in SC09. The SipD presents a distinct domain organization: an $\alpha$-helical hairpin located in the $\mathrm{N}$-terminal, a mixed structural elements in the $\mathrm{C}$-terminal region, and a coiled-coil domain located in the central part (Figure S5). This protein is not only responsible for forming the needle tip, but is also thought to provide a platform for the formation of a pore on the host cell membrane [43]. The pore is composed of two interacting translocator proteins [30], SipB and SipC, encoded by sipB and sipC (NJ56_03865 and NJ56_03870). T3SS-mediated delivery of effector proteins into eukaryotic cells is mediated by the SipB and SipC [30]. Although the translocases are not well conserved at the primary amino acid sequence level (Figure 4), both of them have the $\alpha$-helical domain with transmembrane helices (Figure S5). In addition, InvB, SicA, SipA, and SicP are type III secretion-associated molecular chaperones for various effector proteins [35] and they are encoded by invB, sicA, sipA, and sicP, respectively (NJ56_03815, NJ56_03860, NJ56_03880, and NJ56_03890). InvJ (encoded by invJ, NJ56_03830) is responsible for proper needle complex assembly. In the absence of invJ, assembly of the inner rod does not take place [44]. An effector protein, SptP (encoded by sptp, NJ56_03895), was identified and contains a tyrosine domain. Once the bacteria are internalized, the SptP can mediate the recovery of the integrity of a host cell membrane by reconstructing the cytoskeleton [45]. Another positive transcriptional activator, InvF (encoded by invF, NJ56_03795), belonging to the AraC family (blue, Figure 3), is involved in a regulatory pathway that leads to the activation of the inv-spa-sic-sip-iac-sic-spt operon [46]. $h p t, h p, h k$, and 03750 (NJ56_03735-NJ56_03750) are comprised of a two-component signal transduction system (blue, Figure 3), which may be the central regulator in the overall scheme of SC09-T3SS regulation and activate expression of the $\mathrm{prg} / \mathrm{org}$, and inv/spa operons.

\section{Yst2}

\section{NJ56_10735-NJ56_10800}

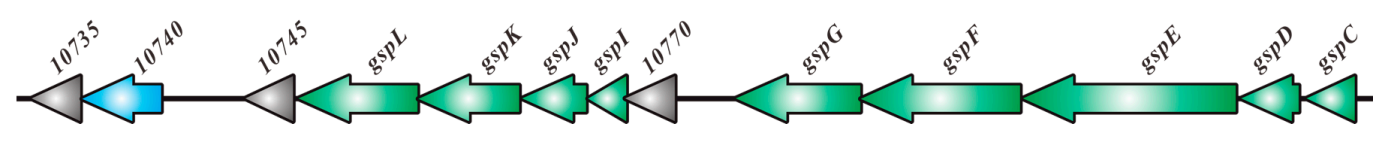

Figure 4. Gene clusters associated with type II secretion system Yst2 in SC09.

SC09 also encodes (NJ56_03910-NJ56_03975) a general secretion pathway (GSP)-like system that is known as type II secretion system (T2SS). Genes for all of the core proteins CDEFGHIJKLMOS in SC09-T2SS have been identified (green, Figure 3), denoted as Yst1, which is located closest to Ysa, which is similar to Y. enterocolitica 8081 and Y. enterocolitica WA-314 (both are in the biotype 1B group) [47]. In addition, Y. ruckeri SC09 possesses a second incomplete T2SS (NJ56_10735-NJ56_10800), denoted as Yst2 (Figure 5), which is located outside of the Ysa-Yst1 region. Many Gram-negative bacteria can secrete folded proteins by the type II secretion system (T2SS) [47]. The T2SS actually play an important role in pathogenic or non-pathogenic species [48]. T2SS-Yst1 and T3SS-Ysa are located closest to each other both in Y. ruckeri SC09 and highly pathogenic Yersinia enterocolitica biotype 1B; this may suggest that Ysa-Yst1 share the same substrates and are likely to facilitate the effects of secretion. 


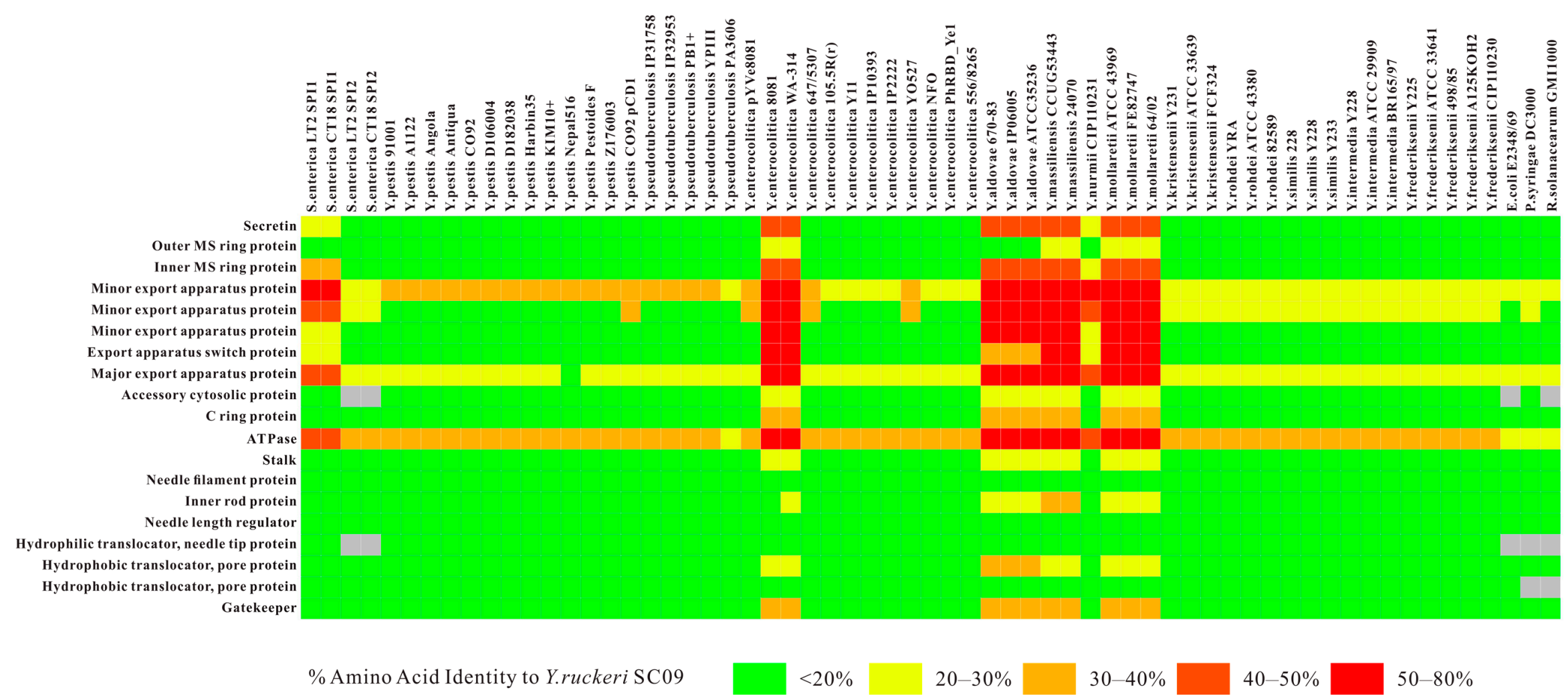

Figure 5. Homologous proteins and their function in various families of T3SSs from different bacteria. Heat map colors are based on the amino acid identity of genes across the T3SS, as indicated in the picture. The percent identities were identified using BLAST searches of the assembled genomes. Amino acid sequences from SC09 act as the comparator sequences. 


\subsection{Comparative Analysis of SC09-T3SS and T3SSs from Different Strains}

T3SS is a key mechanism for host cell interaction used by a wide range of bacterial pathogens with a variety of lifestyles [32]. Thereby, various types of T3SSs are responsible for various niche adaptations. By comparing the amino acid sequences in homologous proteins of T3SS from different bacteria with the related sequences from Y. ruckeri SC09, it is evident that SC09-Ysa is different from the plasmid-encoded T3SSs from Y. pestis, Y. enterocolitica, and chromosome-encoded SPI2-like T3SSs from Y. enterocolitica biotype 1A, 2-5, Y. pestis, Y. pseudotuberculosis, environmental Yersinia, and other types of T3SSs from E. coli, P. syringae, and R. solanacearum; instead, it is closely related to the SPI1-T3SSs and Y. enterocolitica biotype 1B encoded T3SSs (Figure 5). Previous studies have found that the Ysa T3SS from Y. enterocolitica biotype 1B was closely related to the SPI1-encoded T3SS of S. enterica [49]. Further comparative study between SC09-Ysa and SPI1-T3SS from S. enterica indicated that the SC09-Ysa share extensive similarity in gene content and gene arrangement with the Salmonella enterica pathogenicity island 1, SPI1 (Figure 6). Meanwhile, in consideration of the best-conserved ATPase in T3SSs (due to the fact that it displays high sequence homology among different species [50]), we utilized the amino acid sequences of ATPase to produce a T3SS phylogeny in order to investigate the evolution of SC09-Ysa (Figure 7 and Figure S6). Our phylogenetic study has resolved 25 genera into three species clusters, of which $Y$. kristensenii, $Y$. frederiksenii, $Y$. rohdei, Y. intermedia, Y. pekkanenii, Y. similis, Y. pestis, Y. pseudotuberculosis, Y. enterocolitica (non-biotype-1B), Y. aldovae, and S. enterica SPI2 form a cluster (yellow, Figure 7); Y. pestis plasmid pCD1, Y. enterocolitica plasmid pYVe8081, E. coli, P. syringae, and R. solanacearum form the second cluster (blue, Figure 7); and SC09-Ysa, S. enterica SPI1, Y. enterocolitica biotype 1B and Y. mollaretii, Y. massiliensis, and Y. nurmii form the third cluster (green, Figure 7). Hence, phylogenetic analysis with sequence similarity and gene arrangement clearly suggested that SC09-Ysa, SPI1-T3SS, and chromosome-encoded T3SS from Y. enterocolitica biotype 1B may mediate similar biological functions associated with secretion.

All three human pathogenic Yersinia species, Y. pestis, Y. pseudotuberculosis, and Y. enterocolitica, carry a pYV virulence plasmid (also named as $\mathrm{pCD}$ ) that can encode the Ysc type III secretion system and Yops effectors but does not exist in the non-pathogenic population; it was only found in virulent species [51]. Among the three human pathogenic Yersinia, Y. enterocolitica strains are heterogeneous and can be classified into six biotypes (1A, 1B, 2, 3, 4, and 5) based on biochemical properties [52]. Biotype 1A strains, lacking a high pathogenicity island (HPI) and pYV plasmid, are considered avirulent, whereas biotypes $2-5$, only lacking HPI, are low virulence [53]. These five biotypes all belong to the Y. enterocolitica subsp. palearctica and are usually isolated from Europe and Japan (also known as "Old World" strains) [54]. Most notably, the biotype 1B strains (subsp. enterocolitica), carrying both HPI and the pYV plasmid, present the highest virulent among the six biotypes and are mainly found in North America (also termed "New World" strains) [47]. In addition, Salmonella isdivided into two species, bongori and enterica. Both species carry the so-called pathogenicity island 1 (SPI1), a distinct chromosomal operon that encodes a type three secretion system (T3SS-1) [55]. So far, all pathogenic Salmonella belong to the enterica species and carry an additional pathogenicity island named SPI2, which encodes another type of T3SS (T3SS-2) [55]. These two T3SSs both play a role during the infection of eukaryotes [56]. SPI1 mainly facilitates the invasion of non-phagocytic cells of epithelia [36]. SPI2 is responsible for bacterial survival inside the eukaryotic cell and then lays the foundation for a systemic infection [57]. Y. ruckeri SC09 only possesses one SPI1-like T3SS, Ysa, which probably contributes to the development of an intracellular niche in fish. This finding is consistent with the capacity of Y. ruckeri to survive in macrophages of rainbow trout [16], and the SC09-Ysa is likely to become the molecular basis for an invasion of the gill epithelium and gastrointestinal tract epithelium. 

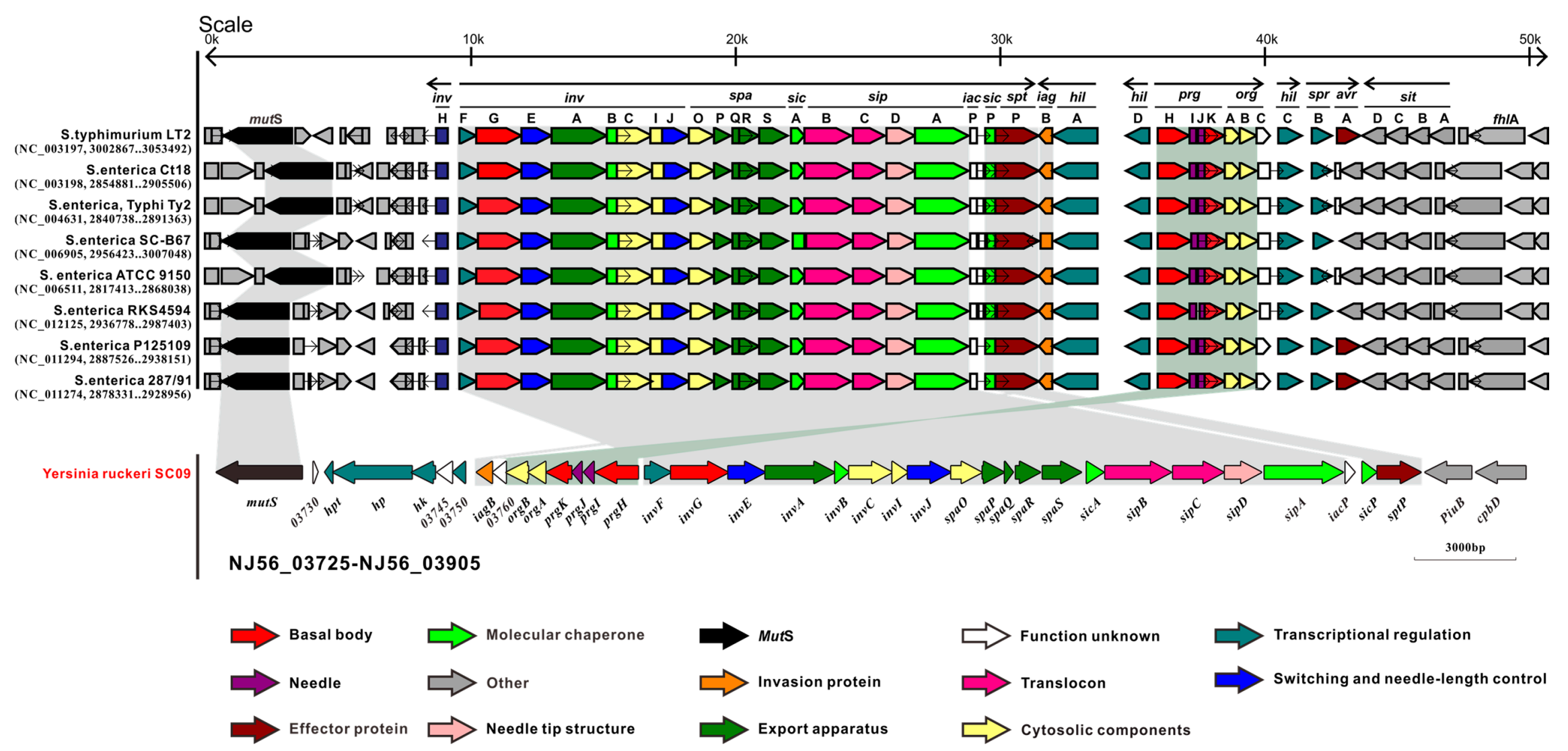

Figure 6. Comparative analysis of the distribution in T3SS between SC09 and SPI1 from Salmonella. 


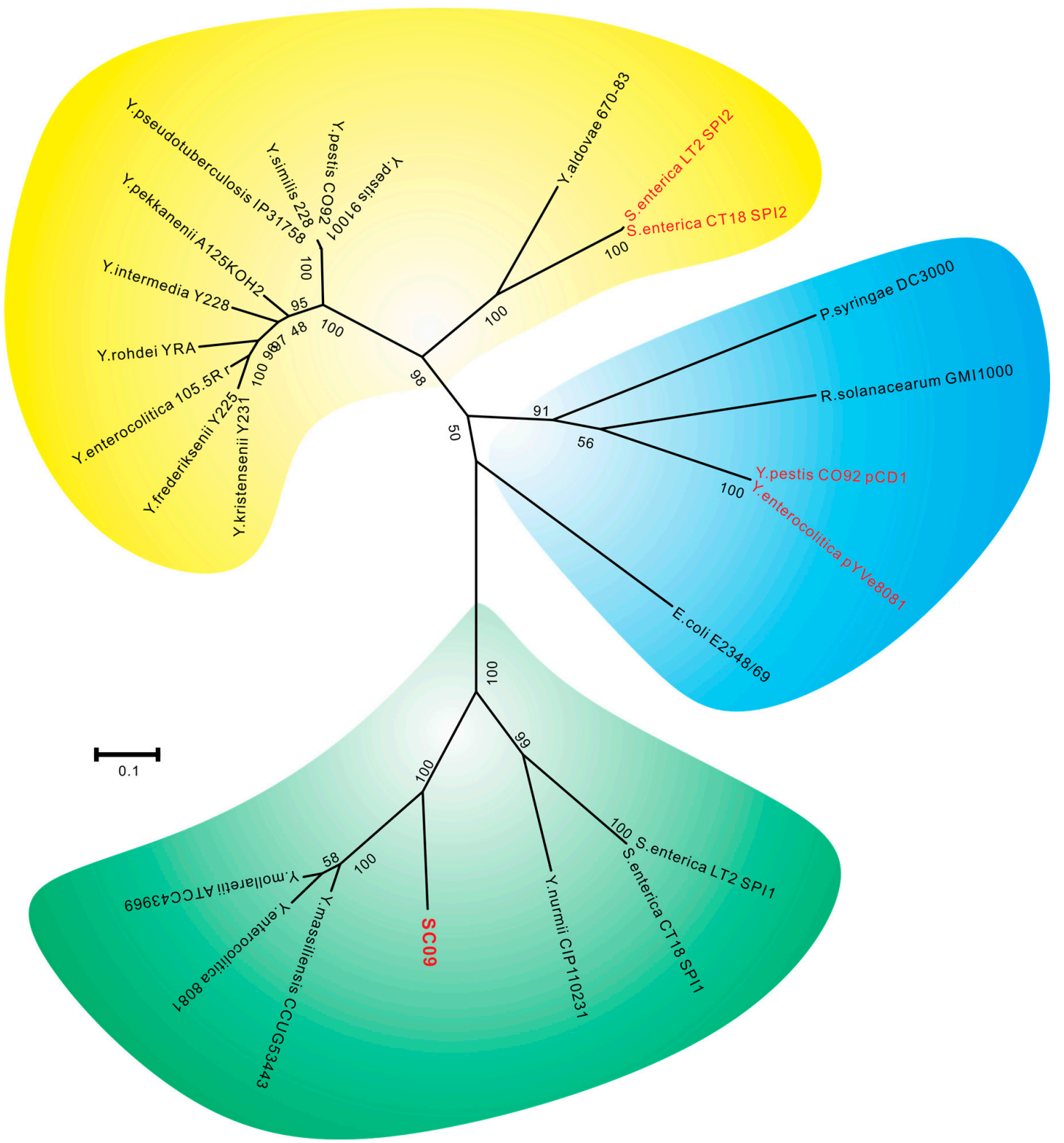

Figure 7. Maximum likelihood phylogenetic tree of the T3SS based on the ATPase amino acid sequences. Values shown on tree branches indicate the percentage of trees among 100 bootstrap replicates carrying that particular branching.

\subsection{Metabolism and Transport Systems}

An overview of the basic metabolic pathways of SC09 is presented in Figure 8. Phosphotransferase system (PTS) plays a major role in transport and metabolism of carbon source in SC09. PTS is in fact a multiprotein transport system that can couple the uptake of carbohydrates through the cytoplasmic membrane with their simultaneous phosphorylation [58]. This type of active transport exists exclusively in bacteria [58]. PTS for transport and metabolism of $\mathrm{N}$-acetyl-glucosamine (NJ56_05450), sucrose (NJ56_16635), cellobiose (NJ56_09805, NJ56_09815-20), mannitol (NJ56_13600), ascorbate (NJ56_08600-05, NJ56_15455-65), glucose (NJ56_07070, NJ56_15910), fructose (NJ56_15025-35), nitrogen (NJ56_11960, NJ56_11970, NJ56_10665), mannose (NJ56_09565-75), trehalose (NJ56_11995, NJ56_15910), glucitol/sorbitol (NJ56_11140-50), and N-acetylga-lactosamine (NJ56_02695-10) were found in the SC09 genome, all of which allow the bacteria to use carbon sources in a hierarchical manner. The SC09 genome also encodes the complete sets of enzymes necessary for glycolysis, the tricarboxylic cycle 
(TCA), and the pentose phosphate pathway, while the gluconeogenesis pathway was not identified (lacking the key gene encoding pyruvate carboxylase). Pyruvate is one of the most important fermentation precursors and plays a key role in anaerobic environments [59]. Analysis of the genome of SC09 showed that the pyruvate from glycolysis could be converted into lactate (mediated by NJ56_05960 and NJ56_08725), formate (mediated by NJ56_06595, NJ56_06600 and NJ56_11180), and acetate (mediated by NJ56_15445 and NJ56_06880) for fermentation processes (green arrows, Figure 8). On the other hand, the glycolysis and TCA would change their pathway under anaerobic conditions (blue arrows, Figure 8) in order to adapt to the specific living environments of enteric infection, which is also in agreement with $Y$. ruckeri facultative anaerobic lifestyle in intracellular niches [16]. Additionally, pyruvate, phosphoenolpyruvic acid (PEP), Glyceraldehyde-3-P from glycolysis and Oxaloacetate, and 2-Oxoglutarate from TCA are all precursors in the amino acid synthesis of SC09.

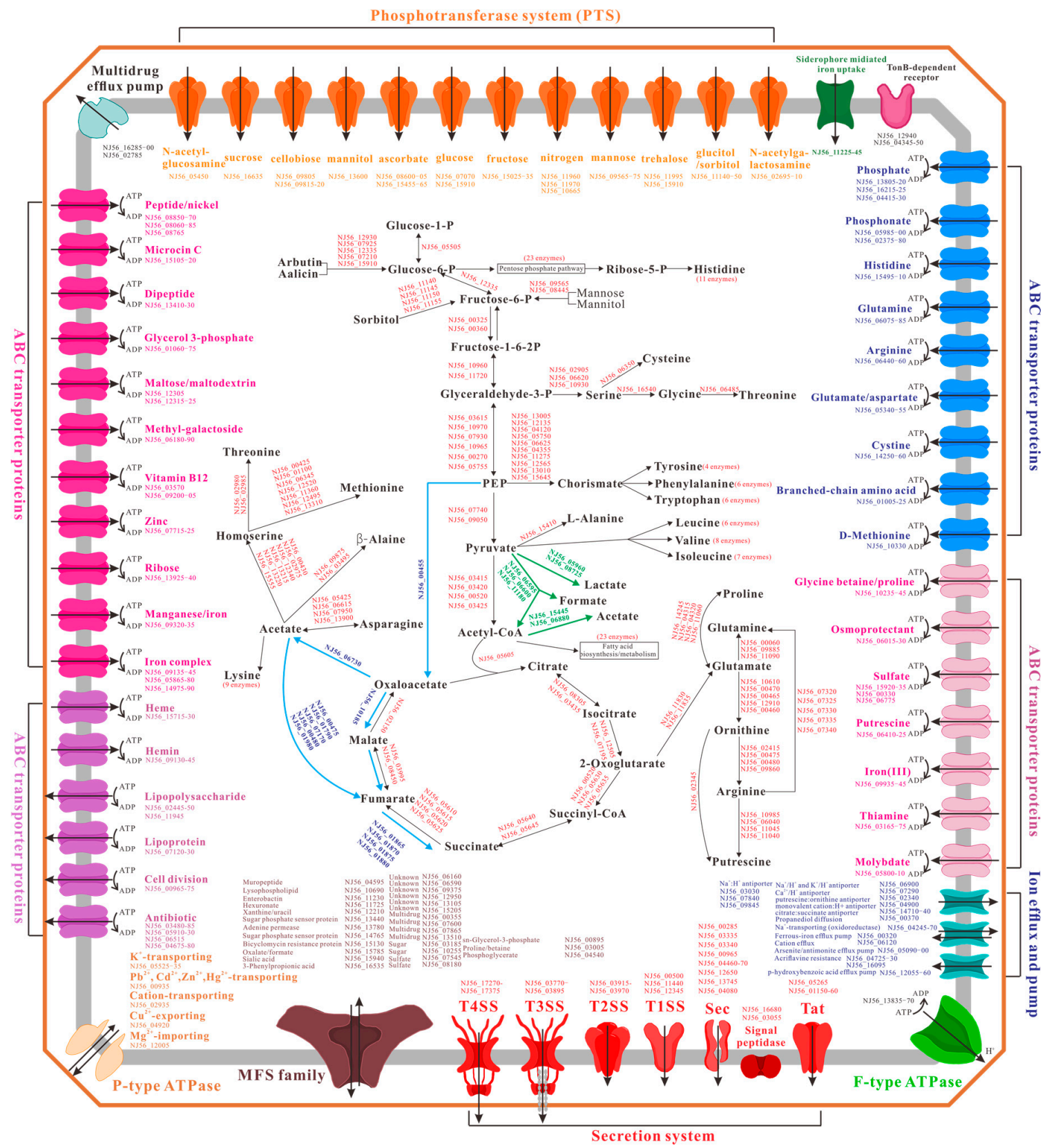

Figure 8. Overview of metabolism and transport in SC09. Different transport families are distinguished by different colors and shapes. 
Adding PTS, the SC09 genome contains about 320 genes associated with a wide variety of transport systems, accounting for $8.7 \%$ of the total genes, and that is a conservative estimate. Identified transporters are listed in Figure 8, including three types of solute transporting ATPases (P-type, F-type, and ABC-type), major facilitator superfamily (MFS) proteins, ion efflux and pump, siderophore-TonB system, multidrug efflux pump, and various secretion systems (Tat, Sec, T1SS, T2SS, T3SS, T4SS). The P-type ATPases constitute a large protein family that pumps ions and lipids across cellular membranes [60]. Of this type of ATPase, NJ56_05525-NJ56_05535 is predicted to encode a $\mathrm{K}^{+}$-transporting ATPase, NJ56_02935 is predicted to encode a cation-transporting ATPase, NJ56_00935 and NJ56_04920 encode P-type ATPases conferring resistance to some toxic metals such as cadmium and copper, and NJ56_12005 is responsible for $\mathrm{Mg}^{2+}$-importing. F-type ATPase can use an electrochemical gradient of $\mathrm{H}^{+}$to synthesize ATP [61], which is encoded by NJ56_13835-NJ56_13870 in the genome. Compared to F-type and P-type ATPases, ABC (ATP-binding cassette) transporters are most abundant in $\mathrm{SC} 09$. ABC transporters, located in the integral membrane, can actively transport a variety of substrates across the bacterial membranes [62]. In fact, this transporter exhibits specificity to a broad range of substrates in different bacteria: carbohydrates, amino acids, inorganic ions, multidrug, oligopeptides, and osmoprotectants [63]. ABC transporters from SC09 genome enable the bacteria to uptake a variety of amino acids (histidine, glutamine, arginine, glutamate/aspartate, cystine, branched-chain amino acid, D-methionine, glycine betaine/proline,), peptides, vitamin B12, ribose, heme, hemin, thiamine, and inorganic ions, and to exude toxic compounds and antibiotics. Similarly, MFS is also one of the largest groups of transporters in bacteria [64]. MFS transporters in SC09 target a wide spectrum of substrates including enterobactin, hexuronate, xanthine/uracil carbohydrates, lipids, amino acids and peptides, nucleosides, antibiotics, and other unknown molecules. Interestingly, we have identified two types of iron transporters in the SC09 genome; one is homologous to the siderophore-dependent [65] iron acquisition systems (encoded by NJ56_11225-45, NJ56_04345-50, NJ56_11230 and NJ56_12940) that bind ferrichrome as a substrate, and the other belongs to the ABC transporters (encoded by NJ56_09135-45, NJ56_05865-80, NJ56_14975-90, and NJ56_09935-45). So, the uptake of iron may be particularly important for SC09 growth.

The capacity of protein secretion is very important for the niche adaptations and pathogenesis of bacteria [66]. Currently, there are a variety of secretion pathways generally including types 1-8 secretion systems and some additional specific protein transportation systems in different bacteria genomes [66]. Among these systems, the Sec-dependent transport system, twin arginine transport system (Tat), T1SS, T2SS, T3SS, and T4SS were all identified in the genome of Y. ruckeri SC09 (Figure 8). We have analyzed T3SS and T2SS, as detailed above. However, unlike other pathogenic Yersinia strains or S. enterica, Y. ruckeri SC09 contains just one copy of SPI1-like T3SS, owing to its specific fish host.

Secreted proteins from bacteria are normally synthesized with amino terminal signal peptides that target them to either the Sec or the Tat protein export pathway [67]. Protein translocation mediated by Tat (NJ56_01150-60 and NJ56_05265) from SC09 allows for the secretion of fully folded proteins and their chaperones, and appears to be able to mediate various stress responses and virulence. By contrast, the Sec apparatus (NJ56_00285, NJ56_03335, NJ56_03340, NJ56_00965, NJ56_04460-70, NJ56_12650, NJ56_13745, and NJ56_04080) from SC09 appears to translocate polypeptides in an unstructured state. In line with previous findings, SC09 harbors a T4SS (type IV secretion system) [68], encoded by NJ56_17270-NJ56_17375, which is closely related to the Agrobacterium tumefaciens VirB system (type IVA). T4SS may take part in the transfer of different effectors into the macrophages or red blood cells, which may facilitate bacterial survival within these cells [69]; this is also in agreement with the facultative anaerobic lifestyle in intracellular niches of $Y$. ruckeri.

\subsection{Stress Adaptation and Signal Transduction}

Bacteria respond to environmental stress generally by some regulatory networks, which can modulate a series of corresponding genes' expression [70]. These response processes are essential for coping with the complicated stress where temperature, availability of nutrients, and presence of 
various chemicals are constantly changing [70]. For Y. ruckeri, quick adaptation to the dynamic aquatic environment or for survival in fish is generally carried out by a series of stress response systems such as alternative $\sigma$ factors, various shock proteins, and two-component signal transduction system (TCS), all of which have been identified in Y. ruckeri SC09 (Tables 4-6).

In bacteria, $\sigma$ factors are prerequisites for the RNA polymerase [71]. Meanwhile, the $\sigma$ factors themselves are regulated by anti- $\sigma$ factors that can bind and inhibit their cognate $\sigma$ factor, and "appropriators" that deploy a particulars-associated RNA polymerase to a specific promoter class [72]. An array of sigma factors and anti-sigma factors were identified in SC09 (Table 4). Among them, $\sigma-32$ and $\sigma^{\mathrm{E}}$, the alternative sigma factors, encoded by rpoH and rpoE (NJ56_00980 and NJ56_16705), appear to be responsible for the heat-shock response. The heat-shock response is specifically induced by a range of so-called heat-shock proteins (HSPs) as a result of a rapid increase in the environmental temperature (Table 5). In SC09, many of the HSPs are molecular chaperones such as GroEL, GroES, DnaK, DnaJ (encoded by NJ56_01805, NJ56_01800, NJ56_03020 and NJ56_03025), and ATP-dependent proteases (e.g., ClpP, Lon, and HsIVU, encoded by NJ56_04615, NJ56_04625, NJ56_00390, and NJ56_00395) that may play a key role in the restoration of protein folding and in protein degradation under normal and stress conditions. The Hsps are essential for protection against various environmental stresses and they can also enhance tolerance to high salt, high temperature, and heavy metals, all of which then contribute to bacterial virulence [73]. These proteins are still highly conserved in nucleotide sequences, whereas the expression and regulation of corresponding genes is highly variable between different organisms and even between various bacteria [73]. In particular, some of the control elements found in $\mathrm{SC} 09$ are heat-shock $\sigma$ factors that regulate the transcription of the major Hsps (Table 4).

Table 4. Sigma factors and anti-sigma factors in SC09.

\begin{tabular}{|c|c|c|c|}
\hline Type & CDS & Gene & Annotation \\
\hline \multirow[t]{7}{*}{ Sigma factor } & NJ56_00980 & rpoH & RNA polymerase factor $\sigma-32$ \\
\hline & NJ56_03720 & rpos & RNA polymerase factor $\sigma-38$ \\
\hline & NJ56_11525 & rpoD & RNA polymerase $\sigma$ factor \\
\hline & NJ56_11950 & rpoN & RNA polymerase factor $\sigma-54$ \\
\hline & NJ56_14270 & fliZ & Flagellar biosynthesis protein FliZ \\
\hline & NJ56_14275 & fliA & Flagellar biosynthesis factor $\sigma-28$ \\
\hline & NJ56_16705 & rpoE & RNA polymerase factor $\sigma-24\left(\sigma^{\mathrm{E}}\right)$ \\
\hline \multirow[t]{9}{*}{ Anti-sigma factor } & NJ56_01355 & rsd & Anti-RNA polymerase $\sigma 70$ factor \\
\hline & NJ56_04135 & raiA & $\sigma-54$ modulation protein \\
\hline & NJ56_05160 & $r s b V$ & Anti-anti- $\sigma$ regulatory factor \\
\hline & NJ56_14465 & $f l g M$ & Anti- $\sigma 28$ factor \\
\hline & NJ56_16690 & rseC & $\sigma$-E factor negative regulatory protein $\mathrm{RseC}$ \\
\hline & NJ56_16695 & rseB & $\sigma$-E factor negative regulatory protein RseB \\
\hline & NJ56_16700 & rseA & $\sigma$-E factor negative regulatory protein RseA \\
\hline & NJ56_05170 & - & Anti- $\sigma$ regulatory factor (Ser/Thr protein kinase) \\
\hline & NJ56_11895 & - & Anti- $\sigma$ B factor antagonist \\
\hline
\end{tabular}

On the other hand, it is well known that fish are poikilotherms whose body temperature changes as the ambient water temperature changes. So, the study of cold-shock response is now in the limelight because of the importance of adaptation to cold environments in bacteria [74]. A temperature reduction will result in the inhibition of bacterial growth and proliferation at different levels, and change the effect of protein expression [75]. The synthesis of most cellular proteins is also inhibited after a decrease in temperature [74]. In response to a temperature downshift, members of a family of small cold-shock proteins (CSPs) appear to be induced by SC09 (Table 5). The CSPs tend to interact with single-stranded RNA or DNA and also play a key role in bacteria physiology under both normal and cold situations [76]. 
In addition, acid shock proteins (encoded by NJ56_08680 and NJ56_10210) may play an important role for Y. ruckeri SC09 in facing the gastrointestinal acid environment in fish (Table 5). Furthermore, SC09 also possesses a phage-shock-protein (Psp) system, pspABCDFG (encoded by NJ56_08825, NJ56_08820, NJ56_08815, NJ56_08810, NJ56_08830, and NJ56_12255), which appears to correspond to functions that help bacteria manage the impacts of agents impairing cell membrane function (Table 5). The Psp system appears to be widely shared by what has been sequenced so far of the Enterobacteria genome (and even across most Gram-negative bacteria genomes), and this system has also been implicated in the virulence of Salmonella, Shigella, and Yersinia [77]. The expression of the $p s p$ genes is likely driven by RNA polymerase containing the $\sigma-54$ factor (encoded by NJ56_11950).

Table 5. Shock proteins in Y. ruckeri SC09.

\begin{tabular}{|c|c|c|}
\hline Shock Protein & Gene & Feature \\
\hline NJ56_05240 & $\operatorname{csp}$ & Cold shock protein \\
\hline NJ56_05245 & $\operatorname{csp} E$ & Cold shock protein \\
\hline NJ56_06525 & $\operatorname{csp} D$ & Cold shock protein \\
\hline NJ56_06665 & $\operatorname{csp} E$ & Cold shock protein \\
\hline NJ56_06670 & $\operatorname{csp} E / \operatorname{csp} D$ & Cold shock protein \\
\hline NJ56_09660 & $\operatorname{csp} \mathrm{C}$ & Cold shock protein \\
\hline NJ56_09775 & $\operatorname{csp} G$ & Cold shock protein \\
\hline NJ56_09780 & $\operatorname{csp} G$ & Cold shock protein \\
\hline NJ56_09785 & $\operatorname{csp} G$ & Cold shock protein \\
\hline NJ56_10190 & $\operatorname{csp} G$ & Cold shock protein \\
\hline NJ56_14650 & $\operatorname{csp} C$ & Cold shock protein \\
\hline NJ56_04805 & $h t p G$ & Heat shock protein 90 \\
\hline NJ56_06870 & $h s p Q$ & Heat shock protein HspQ \\
\hline NJ56_09380 & $h t p X$ & Heat shock protein Htp \\
\hline NJ56_13685 & $i b p B$ & Small heat shock protein IbpB \\
\hline NJ56_13690 & $i b p A$ & Small heat shock protein IbpA \\
\hline NJ56_13060 & $h s l R$ & Ribosome-associated heat shock protein Hsp15 \\
\hline NJ56_16745 & grpE & Heat shock protein GrpE \\
\hline NJ56_01800 & groES & Co-chaperonin GroES (HSP10) \\
\hline NJ56_01805 & groEL & Chaperonin GroEL (HSP60 family) \\
\hline NJ56_08730 & hslJ & Heat shock protein HslJ \\
\hline NJ56_16480 & $h \operatorname{ch} A$ & Chaperone protein HscA \\
\hline NJ56_16250 & yeg $D$ & Hypothetical chaperone protein \\
\hline NJ56_13065 & hslO & Molecular chaperone Hsp33 \\
\hline NJ56_03020 & dnaK & Molecular chaperone DnaK \\
\hline NJ56_03025 & dnaJ & Molecular chaperone DnaJ \\
\hline NJ56_03140 & $\operatorname{djlA}$ & DnaJ like chaperone protein \\
\hline NJ56_08565 & - & Heat shock protein DnaJ-like protein DjlA \\
\hline NJ56_00390 & hsll & ATP-dependent protease ATPase subunit HslU \\
\hline NJ56_00395 & $h s l V$ & ATP-dependent protease ATPase subunit HslV \\
\hline NJ56_04615 & $c l p P$ & ATP-dependent Clp protease proteolytic subunit ClpP \\
\hline NJ56_04620 & $\operatorname{clp} X$ & ATP-dependent Clp protease ATP-binding subunit clpX \\
\hline NJ56_04625 & lon & ATP-dependent protease La \\
\hline NJ56_02295 & deaD & ATP-dependent RNA helicase DeaD \\
\hline NJ56_08680 & - & Acid shock protein \\
\hline NJ56_10210 & - & Acid shock protein 2 precursor \\
\hline NJ56_08825 & $\operatorname{pspA}$ & Phage shock protein A \\
\hline NJ56_08820 & $p s p B$ & Phage shock protein B \\
\hline NJ56_08815 & pspC & Phage shock protein $\mathrm{C}$ \\
\hline NJ56_08810 & pspD & Phage shock protein D \\
\hline NJ56_08830 & pspF & Psp operon transcriptional activator \\
\hline NJ56_12255 & $\operatorname{pspG}$ & Phage shock protein $G$ \\
\hline
\end{tabular}

The two-component signal transduction system (TCS), comprised of sensor histidine kinases $(\mathrm{HK})$ and their cognate response regulator (RR) substrates, is one of the most prevalent means by 
which bacteria sense, respond, and adapt to complex environment changes or their time-varying intracellular state [78]. SC09 harbors a number of TCSs including 23 HK genes and 23 RR genes (Table 6). Among them, NJ56_03735 and NJ56_03740 are predicted to mediate the expression of T3SS in SC09, as mentioned above (Figures 3 and 6). Moreover, the ArcB-ArcA phosphorelay (encoded by NJ56_11820 and NJ56_02970) and CitA-CitB (encoded by NJ56_14745 and NJ56_14750) are associated with the switch from aerobic to anaerobic growth (blue pathway and green pathway in Figure 8) in SC09, which is important for intestinal anaerobic bacteria [79]. The PhoR-PhoB two-component system (encoded by NJ56_04410 and NJ56_04405) allows the organism to sense and respond to changes in phosphate availability. The PhoQ-PhoP pathway (encoded by NJ56_07155 and NJ56_07160) may regulate the expression of a large collection of genes in response to conditions of low $\mathrm{Mg}^{2+}$. Meanwhile, chemotaxis in SC09 involves a histidine kinase CheA (encoded by NJ56_14595) that phosphorylates two response regulators, CheY (encoded by NJ56_14565) and CheB (encoded by NJ56_14570). Phosphorylation of each regulator by CheA may be necessary for a proper chemotactic response. The pgt system (phosphoglycerate transport system [80]) is probably a TCS (encoded by NJ56_04525, NJ56_04530, NJ56_04535, and NJ56_04540) and may contribute to the development of an intracellular niche for SC09. Other TCSs may also mediate adaptive responses to a broad range of environmental stimuli (Table 6).

Table 6. Two-component signal transduction system in Y. ruckeri SC09.

\begin{tabular}{|c|c|c|c|c|}
\hline $\begin{array}{l}\text { Histidine Protein } \\
\text { Kinase (HK) }\end{array}$ & $\begin{array}{c}\text { Response } \\
\text { Regulator (RR) }\end{array}$ & HK Gene & RR Gene & Putative Functions \\
\hline NJ56_14745 & NJ56_14750 & citA & citB & Citrate fermentation \\
\hline NJ56_00055 & NJ56_00050 & $g \ln L$ & $g \ln G$ & Nitrogen assimilation \\
\hline NJ56_03735 & NJ56_03740 & $h p$ & $h k$ & Type III secretion system \\
\hline NJ56_00305 & NJ56_00310 & $\operatorname{cpx} A$ & $\operatorname{cpxR}$ & Cell envelop protein folding, degradation \\
\hline NJ56_02195 & NJ56_02200 & bass & basR & \\
\hline NJ56_11820 & NJ56_02970 & $\operatorname{arcB}$ & $\operatorname{arc} A$ & Anaerobic respiration \\
\hline NJ56_03590 & NJ56_14200 & barA & uvrY & Carbon storage regulation, regulate \\
\hline NJ56_07200 & NI56 07230 & $\begin{array}{l}\text { sdiA } \\
\text { dcuS }\end{array}$ & & $\begin{array}{l}\text { swarming and quorum sensing } \\
\text { Anaerobic fumarate respiratory system }\end{array}$ \\
\hline NJ56_07235 & $\begin{array}{l}\text { NJ56_07230 } \\
\text { NJ56_04405 }\end{array}$ & phoR & $\begin{array}{l}\text { dcuR } \\
\text { phoB }\end{array}$ & $\begin{array}{l}\text { Anaerobic fumarate respiratory system } \\
\text { Phosphate limitation }\end{array}$ \\
\hline $\begin{array}{l}\text { NJ56_04410 } \\
\text { NI56 } 07155\end{array}$ & $\begin{array}{l}\text { NJ56_04405 } \\
\text { NJ56_07160 }\end{array}$ & phoQ & phoP & Antimicrobial peptide resistance, virulence \\
\hline NJ56_04530 & NJ56_04525 & $p g t B$ & $\operatorname{pgt} A$ & Phosphoglycerate transport \\
\hline NJ56_04785 & NJ56_04780 & tctE & $t c t D$ & Tricarboxylates transport \\
\hline NJ56_05520 & NJ56_05515 & $k d p D$ & $k d p E$ & Potassium transport \\
\hline NJ56_13075 & NJ56_13080 & envZ & $o m p R$ & Osmosis regulation \\
\hline NJ56_08655 & NJ56_08650 & $r s t B$ & rstA & Stress \\
\hline NJ56_16305 & NJ56_16310 & baes & baeR & Multidrug efflux \\
\hline $\begin{array}{l}\text { NJ56_15220 } \\
\text { NJ56_10345 }\end{array}$ & NJ56_15210 & $\begin{array}{l}r c s C \\
r c s F\end{array}$ & $r c s D$ & Capsular polysaccharide synthesis \\
\hline NJ56_16600 & $\begin{array}{l}\text { NJ56_16590 } \\
\text { NJ56_11950 }\end{array}$ & $q s e E$ & $\begin{array}{l}q s e F \\
\text { rpoN }\end{array}$ & Attaching and effacing lesions \\
\hline NJ56_13445 & NJ56_13450 & $u h p B$ & uhpA & Hexose phosphate transport \\
\hline NJ56_14760 & NJ56_14755 & uhpB & uhpA & Hexose phosphate transport \\
\hline NJ56_14595 & $\begin{array}{l}\text { NJ56_14570 } \\
\text { NJ56_14565 }\end{array}$ & cheA & $\begin{array}{l}\text { cheB } \\
\text { cheY }\end{array}$ & Bacterial chemotaxis \\
\hline NJ56_15775 & NJ56_15780 & Unclear & Unclear & - \\
\hline
\end{tabular}

\section{Materials and Methods}

\subsection{Bacterial Growth and DNA Extraction}

Biotype 1 Y. ruckeri SC09 was isolated from diseased Ictalurus punctatus in a reservoir farm in Jianyang, Sichuan province of China and was routinely cultured on a Luria-Bertani (LB) medium at $28{ }^{\circ} \mathrm{C}$. Genomic DNA was isolated from $10 \mathrm{~mL}$ overnight culture using the TIANamp Bacteria DNA 
Kit (TIANGEN Biotech, Beijing, China). DNA was dissolved in TE buffer (10 mM Tris-HCl, $1 \mathrm{mM}$ EDTA, pH 8.0). Genome sequencing was performed by Novogene (Beijing, China).

\subsection{DNA Sequencing}

Two different genomic DNA libraries were constructed according to the manufacturer's instructions for the Illumina HiSeq 2000 platform (Novogene, Beijing, China) and the Illumina Miseq platform (Novogene, Beijing, China). Long-insert (2-6 kb) libraries were sequenced using Illumina HiSeq 2000 by the paired end mode, and short-insert (500 bp) libraries were sequenced with Illumina Miseq in the manner of paired end mode.

\subsection{Assembly}

Low-quality reads were filtered, and high-quality reads were used for de novo assembly. Short reads were assembled using the SOAPdenovo alignment tool (version 2.04), a genome assembler developed particularly for second-generation short-read sequences. The SOAP GapCloser was then used to close gaps where possible after assembly.

\subsection{Sequence Analysis and Annotation}

The protein-coding genes were predicted by the software Glimmer 3.02 [81], while tRNAscan-SE [82] and RNAmmer [83] were used to seek out tRNA and rRNA, respectively. The genome sequence was then uploaded into Rapid Annotation using Subsystem Technology (RAST), which can provide high-quality genome annotations for prokaryotes [84], to find the annotated sequences. The functions of predicted protein-coding genes were subsequently annotated through comparisons with the databases of NCBI-NR, COG, and KEGG. To determine the phylogenetic relationship of T3SS from different genus, we constructed a maximum likelihood phylogenetic tree using MEGA 6.0.6 [85] with the WAG model, further applying 1000 bootstrap replicates. The tree was based on the amino acid sequences encoding T3SS-ATPase. We also used the SWISS-MODEL and TMHMM Server v. 2.0 to predict protein tertiary structure and protein transmembrane regions, respectively, from SC09-Ysa.

\subsection{Search for Genes and Operons Related to Type III Secretion System (T3SS)}

T3SS genes were identified using BLAST searches of the assembled genomes (Table S1). Heatmap colors are based upon amino acid identity across the genes in the operon, as indicated in Figure 5.

\subsection{Data Availability}

The nucleotide sequence of the Y. ruckeri SC09 chromosome was submitted to the GenBank database under accession numbers JRWX00000000.

\subsection{Histopathology}

Tissue samples (liver, kidney, spleen, and intestine collected from diseased Ictalurus punctatus) were fixed in $10 \%$ neutral buffered formalin for one week, and then routinely processed and embedded in paraffin wax. Sections (thickness $0.3 \mu \mathrm{m}$ ) were stained routinely with hematoxylin and eosin, and examined by light microscopy.

\section{Conclusions}

Yersinia ruckeri is the causative agent of enteric red mouth disease in various fish species, and this organism is well established as one of the leading fish pathogens hurting the aquaculture industry around the world [1]. The first commercially available fish vaccine was an immersion vaccine against ERM consisting of $Y$. ruckeri bacterin [15]. In this study, we have determined the complete genome 
sequence of $Y$. ruckeri SC09, a highly virulent strain isolated from Ictalurus punctatus that causes severe septicemia. The comprehensive analysis of the genome sequence provides evidence that the SPI1-like T3SS Ysa appears to play an important role in intracellular infection of Y. ruckeri and the metabolism pathway associated with anaerobic conditions and the genes encoding TCSs, sigma factors, and shock proteins may be applied to increase SC09 survival ability in intestinal environment of fish. Both of them provide genetic information on niche adaptation and the pathogenic mechanism of Y. ruckeri. This study also provides a genetic framework for future studies on the evolution of virulence and physiology characteristics in Y. ruckeri.

Supplementary Materials: Supplementary materials can be found at http://www.mdpi.com/1422-0067/ $17 / 4 / 557 /$ s1.

Acknowledgments: This work was supported jointly by the Sichuan Technology Support Planning (No. 2014NZ0003) of the Sichuan Agricultural University (No. IRT0848) and the Science and Technology Support Program of the Science \& Technology Department of Sichuan Province (No. 2014NZ0003).

Author Contributions: Tao Liu conducted data analysis and wrote the manuscript; Kai-Yu Wang provided the conceptual framework, experimental design, and helped write the manuscript; Jun Wang, De-Fang Chen, Xiao-Li Huang, Yi Geng and Ping Ouyang conducted laboratory work associated with genome sequencing; Yang He conducted data analysis and genome assembly. Yi Zhou and Jie Min conducted laboratory work associated with the survey of histopathology in diseased Ictalurus punctatus. All authors read and approved the final manuscript.

Conflicts of Interest: The authors declare no conflict of interest.

\section{References}

1. Kumar, G.; Menanteau-Ledouble, S.; Saleh, M.; El-Matbouli, M. Yersinia ruckeri, the causative agent of enteric redmouth disease in fish. Vet. Res. 2015, 46, 1-10. [CrossRef] [PubMed]

2. Tobback, E.; Decostere, A.; Hermans, K.; Haesebrouck, F.; Chiers, K. Yersinia ruckeri infections in salmonid fish. J. Fish Dis. 2007, 30, 257-268. [CrossRef] [PubMed]

3. Calvez, S.; Fournel, C.; Douet, D.; Daniel, P. Pulsed-field gel electrophoresis and multi locus sequence typing for characterizing genotype variability of Yersinia ruckeri isolated from farmed fish in France. Vet. Res. 2015, 46, 1-13. [CrossRef] [PubMed]

4. Calvez, S.; Gantelet, H.; Blanc, G.; Douet, D.; Daniel, P. Yersinia ruckeri Biotypes 1 and 2 in France: Presence and antibiotic susceptibility. Dis. Aquat. Organ. 2014, 109, 117-126. [CrossRef] [PubMed]

5. Huang, Y.; Runge, M.; Michael, G.B.; Schwarz, S.; Jung, A.; Steinhagen, D. Biochemical and molecular heterogeneity among isolates of Yersinia ruckeri from rainbow trout (Oncorhynchus mykiss, Walbaum) in north west Germany. BMC Vet. Res. 2013, 9, 215. [CrossRef] [PubMed]

6. Ström-Bestor, M.; Mustamäki, N.; Heinikainen, S.; Hirvelä-Koski, V.; Verner-Jeffreys, D.; Wiklund, T. Introduction of Yersinia ruckeri biotype 2 into Finnish fish farms. Aquaculture 2010, 308, 1-5. [CrossRef]

7. Amend, D.F.; Johnson, K.A.; Croy, T.R.; McCarthy, D.H. Some factors affecting the potency of Yersinia ruckeri bacterins. J. Fish Dis. 1983, 6, 337-344. [CrossRef]

8. Plant, K.P.; LaPatra, S.E. Advances in fish vaccine delivery. Dev. Comp. Immunol. 2011, 35, 1256-1262. [CrossRef] [PubMed]

9. Collis, R.O.; Foster, G.; Ross, H.M. Isolation of Yersinia ruckeri from an otter and salmonid fish from adjacent freshwater catchments. Vet. Rec. 1996, 139. [CrossRef]

10. Vuillaume, A.; Brun, R.; Chene, P.; Sochon, E.; Lesel, R. First isolation of Yersinia ruckeri from sturgeon, Acipenser baeri Brandt, in south west of France. Bull. Eur. Assoc. Fish Pathol. 1987, 7, 18-19.

11. Enriquez, R.; Zamora, J. Aislamiento de Yersinia ruckeri de carpas (Cyprinus carpio) en Valdivia. Arch. Med. Vet. 1987, 19, 33-36.

12. Arias, C.R.; Olivares-Fuster, O.; Hayden, K.; Shoemaker, C.A.; Grizzle, J.M.; Klesius, P.H. First report of Yersinia ruckeri biotype 2 in the USA. J. Aquat. Anim. Health 2007, 19, 35-40. [CrossRef] [PubMed]

13. Austin, D.A.; Robertson, P.; Austin, B. Recovery of a new biogroup of Yersinia ruckeri from diseased rainbow trout (Oncorhynchus mykiss, Walbaum). Syst. Appl. Microbiol. 2003, 26, 127-131. [CrossRef] [PubMed]

14. Fan, F.; Wang, K.; Geng, Y.; Huang, X.; Chen, D. Isolation, identification and phylogenetic analysis of Yersinia ruckeri in channel catfish ictalures punctatus. Oceanol. Limnol. Sin. 2010, 41, 862-868. 
15. Ohtani, M.; Villumsen, K.R.; Koppang, E.O.; Raida, M.K. Global 3D imaging of Yersinia ruckeri bacterin uptake in rainbow trout fry. PLOS ONE 2015, 10. [CrossRef] [PubMed]

16. Ryckaert, J.; Bossier, P.; D’Herde, K.; Diez-Fraile, A.; Sorgeloos, P.; Haesebrouck, F.; Pasmans, F. Persistence of Yersinia ruckeri in trout macrophages. Fish Shellfish Immunol. 2010, 29, 648-655. [CrossRef] [PubMed]

17. Navais, R.; Méndez, J.; Pérez-Pascual, D.; Cascales, D.; Guijarro, J.A. The yrpAB operon of Yersinia ruckeri encoding two putative U32 peptidases is involved in virulence and induced under microaerobic conditions. Virulence 2014, 5, 619-624. [CrossRef] [PubMed]

18. Qin, Z.; Baker, A.T.; Raab, A.; Huang, S.; Wang, T.; Yu, Y.; Jaspars, M.; Secombes, C.J.; Deng, H. The fish pathogen Yersinia ruckeri produces holomycin and uses an RNA methyltransferase for self-resistance. J. Biol. Chem. 2013, 288, 14688-14697. [CrossRef] [PubMed]

19. Méndez, J.; Reimundo, P.; Pérez-Pascual, D.; Navais, R.; Gómez, E.; Guijarro, J.A. A novel cdsAB operon is involved in the uptake of L-cysteine and participates in the pathogenesis of Yersinia ruckeri. J. Bacteriol. 2011, 193, 944-951. [CrossRef] [PubMed]

20. Dahiya, I.; Stevenson, R. Yersinia ruckeri genes that attenuate survival in rainbow trout (Oncorhynchus mykiss) are identified using signature-tagged mutants. Vet. Microbiol. 2010, 144, 399-404. [CrossRef] [PubMed]

21. Dahiya, I.; Stevenson, R. The ZnuABC operon is important for Yersinia ruckeri infections of rainbow trout, Oncorhynchus mykiss (Walbaum). J. Fish Dis. 2010, 33, 331-340. [CrossRef] [PubMed]

22. Dahiya, I.; Stevenson, R. The UvrY response regulator of the BarA-UvrY two-component system contributes to Yersinia ruckeri infection of rainbow trout (Oncorhynchus mykiss). Arch. Microbiol. 2010, 192, 541-547. [CrossRef] [PubMed]

23. Fernández, L.; Méndez, J.; Guijarro, J.A. Molecular virulence mechanisms of the fish pathogen Yersinia ruckeri. Vet. Microbiol. 2007, 125, 1-10.

24. Temprano, A.; Riano, J.; Yugueros, J.; Gonzalez, P.; Castro, L.; Villena, A.; Luengo, J.M.; Naharro, G. Potential use of a Yersinia ruckeri $\mathrm{O} 1$ auxotrophic aroA mutant as a live attenuated vaccine. J. Fish Dis. 2005, 28, 419-427. [CrossRef] [PubMed]

25. Fernandez, L.; Marquez, I.; Guijarro, J.A. Identification of specific in vivo-induced (ivi) genes in Yersinia ruckeri and analysis of ruckerbactin, a catecholate siderophore iron acquisition system. Appl. Environ. Microbiol. 2004, 70, 5199-5207. [CrossRef] [PubMed]

26. Johnson, S.L.; Daligault, H.E.; Davenport, K.W.; Jaissle, J.; Frey, K.G.; Ladner, J.T.; Broomall, S.M.; Bishop-Lilly, K.A.; Bruce, D.C.; Coyne, S.R. Thirty-two complete genome assemblies of nine Yersinia species, including Y. pestis, Y. pseudotuberculosis, and Y. enterocolitica. Genome Announc. 2015, 3, e115-e148. [CrossRef] [PubMed]

27. Nelson, M.C.; LaPatra, S.E.; Welch, T.J.; Graf, J. Complete genome sequence of Yersinia ruckeri strain CSF007-82, etiologic agent of red mouth disease in salmonid fish. Genome Announc. 2015, 3, e1414-e1491. [CrossRef] [PubMed]

28. Navas, E.; Bohle, H.; Henríquez, P.; Grothusen, H.; Bustamante, F.; Bustos, P.; Mancilla, M. Draft genome sequence of the fish pathogen Yersinia ruckeri strain 37551, serotype O1b, isolated from diseased, vaccinated Atlantic salmon (Salmo salar) in Chile. Genome Announc. 2014, 2, e814-e858. [CrossRef] [PubMed]

29. Wang, K.; Liu, T.; Wang, J.; Chen, D.; Wu, X.; Jiang, J.; Liu, J. Complete genome sequence of the fish pathogen Yersinia ruckeri strain SC09, isolated from diseased Ictalurus punctatus in China. Genome Announc. 2015, 3, e1314-e1327. [CrossRef] [PubMed]

30. Galán, J.E.; Lara-Tejero, M.; Marlovits, T.C.; Wagner, S. Bacterial type III secretion systems: Specialized nanomachines for protein delivery into target cells. Annu. Rev. Microbiol. 2014, 68, 415-438. [CrossRef] [PubMed]

31. Izore, T.; Job, V.; Dessen, A. Biogenesis, regulation, and targeting of the type III secretion system. Structure 2011, 19, 603-612. [CrossRef] [PubMed]

32. Büttner, D. Protein export according to schedule: Architecture, assembly, and regulation of type III secretion systems from plant-and animal-pathogenic bacteria. Microbiol. Mol. Biol. Rev. 2012, 76, 262-310. [CrossRef] [PubMed]

33. Hensel, M. Evolution of pathogenicity islands of Salmonella enterica. Int. J. Med. Microbiol. 2004, 294, 95-102. [CrossRef] [PubMed] 
34. Ellermeier, J.R.; Slauch, J.M. Adaptation to the host environment: Regulation of the SPI1 type III secretion system in Salmonella enterica serovar Typhimurium. Curr. Opin. Microbiol. 2007, 10, 24-29. [CrossRef] [PubMed]

35. Dieye, Y.; Ameiss, K.; Mellata, M.; Curtiss, R. The Salmonella Pathogenicity Island (SPI) 1 contributes more than SPI2 to the colonization of the chicken by Salmonella enterica serovar Typhimurium. BMC Microbiol. 2009, 9, 3. [CrossRef] [PubMed]

36. Moest, T.P.; Méresse, S. Salmonella T3SSs: Successful mission of the secret (ion) agents. Curr. Opin. Microbiol. 2013, 16, 38-44. [CrossRef] [PubMed]

37. Srikanth, C.V.; Mercado-Lubo, R.; Hallstrom, K.; McCormick, B.A. Salmonella effector proteins and host-cell responses. Cell. Mol. Life Sci. 2011, 68, 3687-3697. [CrossRef] [PubMed]

38. Diepold, A.; Wagner, S. Assembly of the bacterial type III secretion machinery. FEMS Microbiol. Rev. 2014, 38, 802-822. [CrossRef] [PubMed]

39. Worrall, L.J.; Lameignere, E.; Strynadka, N.C. Structural overview of the bacterial injectisome. Curr. Opin. Microbiol. 2011, 14, 3-8. [CrossRef] [PubMed]

40. Spreter, T.; Yip, C.K.; Sanowar, S.; André, I.; Kimbrough, T.G.; Vuckovic, M.; Pfuetzner, R.A.; Deng, W.; Angel, C.Y.; Finlay, B.B. A conserved structural motif mediates formation of the periplasmic rings in the type III secretion system. Nat. Struct. Mol. Biol. 2009, 16, 468-476. [CrossRef] [PubMed]

41. Abrusci, P.; Vergara-Irigaray, M.; Johnson, S.; Beeby, M.D.; Hendrixson, D.R.; Roversi, P.; Friede, M.E.; Deane, J.E.; Jensen, G.J.; Tang, C.M. Architecture of the major component of the type III secretion system export apparatus. Nat. Struct. Mol. Biol. 2013, 20, 99-104. [CrossRef] [PubMed]

42. Mueller, C.A.; Broz, P.; Müller, S.A.; Ringler, P.; Erne-Brand, F.; Sorg, I.; Kuhn, M.; Engel, A.; Cornelis, G.R. The V-antigen of Yersinia forms a distinct structure at the tip of injectisome needles. Science 2005, 310, 674-676. [CrossRef] [PubMed]

43. Johnson, S.; Roversi, P.; Espina, M.; Olive, A.; Deane, J.E.; Birket, S.; Field, T.; Picking, W.D.; Blocker, A.J.; Galyov, E.E. Self-chaperoning of the type III secretion system needle tip proteins IpaD and BipD. J. Biol. Chem. 2007, 282, 4035-4044. [CrossRef] [PubMed]

44. Rüssmann, H.; Kubori, T.; Sauer, J.; Galán, J.E. Molecular and functional analysis of the type III secretion signal of the Salmonella enterica InvJ protein. Mol. Microbiol. 2002, 46, 769-779. [CrossRef] [PubMed]

45. Agbor, T.A.; McCormick, B.A. Salmonella effectors: Important players modulating host cell function during infection. Cell. Microbiol. 2011, 13, 1858-1869. [CrossRef] [PubMed]

46. Golubeva, Y.A.; Sadik, A.Y.; Ellermeier, J.R.; Slauch, J.M. Integrating global regulatory input into the Salmonella pathogenicity island 1 type III secretion system. Genetics 2012, 190, 79-90. [CrossRef] [PubMed]

47. Thomson, N.R.; Howard, S.; Wren, B.W.; Holden, M.T.; Crossman, L.; Challis, G.L.; Churcher, C.; Mungall, K.; Brooks, K.; Chillingworth, T. The complete genome sequence and comparative genome analysis of the high pathogenicity Yersinia enterocolitica strain 8081. PLoS Genet. 2006, 2, e206. [CrossRef] [PubMed]

48. Korotkov, K.V.; Sandkvist, M.; Hol, W.G. The type II secretion system: Biogenesis, molecular architecture and mechanism. Nat. Rev. Microbiol. 2012, 10, 336-351. [CrossRef] [PubMed]

49. Walker, K.A.; Miller, V.L. Synchronous gene expression of the Yersinia enterocolitica Ysa type III secretion system and its effectors. J. Bacteriol. 2009, 191, 1816-1826. [CrossRef] [PubMed]

50. Ibuki, T.; Imada, K.; Minamino, T.; Kato, T.; Miyata, T.; Namba, K. Common architecture of the flagellar type III protein export apparatus and F-and V-type ATPases. Nat. Struct. Mol. Biol. 2011, 18, 277-282. [CrossRef] [PubMed]

51. Chen, P.E.; Cook, C.; Stewart, A.C.; Nagarajan, N.; Sommer, D.D.; Pop, M.; Thomason, B.; Thomason, M.P.; Lentz, S.; Nolan, N. Genomic characterization of the Yersinia genus. Genome Biol. 2010, 11, R1. [CrossRef] [PubMed]

52. Wauters, G.; Kandolo, K.; Janssens, M. Revised biogrouping scheme of Yersinia enterocolitica. Contrib. Microbiol. Immunol. 1987, 9, 14-21. [PubMed]

53. Garzetti, D.; Bouabe, H.; Heesemann, J.; Rakin, A. Tracing genomic variations in two highly virulent Yersinia enterocolitica strains with unequal ability to compete for host colonization. BMC Genom. 2012, $13,467$. [CrossRef] [PubMed]

54. Schubert, S.; Rakin, A.; Heesemann, J. The Yersinia high-pathogenicity island (HPI): Evolutionary and functional aspects. Int. J. Med. Microbiol. 2004, 294, 83-94. [CrossRef] [PubMed] 
55. Sabbagh, S.C.; Forest, C.G.; Lepage, C.; Leclerc, J.; Daigle, F. So similar, yet so different: Uncovering distinctive features in the genomes of Salmonella enterica serovars Typhimurium and Typhi. FEMS Microbiol. Lett. 2010, 305, 1-13. [CrossRef] [PubMed]

56. McGhie, E.J.; Brawn, L.C.; Hume, P.J.; Humphreys, D.; Koronakis, V. Salmonella takes control: Effector-driven manipulation of the host. Curr. Opin. Microbiol. 2009, 12, 117-124. [CrossRef] [PubMed]

57. Kuhle, V.; Hensel, M. Cellular microbiology of intracellular Salmonella enterica: Functions of the type III secretion system encoded by Salmonella pathogenicity island 2. Cell. Mol. Life Sci. 2004, 61, 2812-2826. [CrossRef] [PubMed]

58. Deutscher, J.; Francke, C.; Postma, P.W. How phosphotransferase system-related protein phosphorylation regulates carbohydrate metabolism in bacteria. Microbiol. Mol. Biol. Rev. 2006, 70, 939-1031. [CrossRef] [PubMed]

59. Muñoz Elías, E.J.; McKinney, J.D. Carbon metabolism of intracellular bacteria. Cell. Microbiol. 2006, 8, 10-22. [CrossRef] [PubMed]

60. Palmgren, M.G.; Nissen, P. P-type ATPases. Annu. Rev. Biophys. 2011, 40, 243-266. [CrossRef] [PubMed]

61. Meier, T.; Polzer, P.; Diederichs, K.; Welte, W.; Dimroth, P. Structure of the rotor ring of F-Type Na+-ATPase from Ilyobacter tartaricus. Science 2005, 308, 659-662. [CrossRef] [PubMed]

62. Dawson, R.J.; Locher, K.P. Structure of a bacterial multidrug ABC transporter. Nature 2006, 443, $180-185$. [CrossRef] [PubMed]

63. Holland, I.B.; Schmitt, L.; Young, J. Type 1 protein secretion in bacteria, the ABC-transporter dependent pathway (review). Mol. Membr. Biol. 2005, 22, 29-39. [CrossRef] [PubMed]

64. Yan, N. Structural advances for the major facilitator superfamily (MFS) transporters. Trends Biochem. Sci. 2013, 38, 151-159. [CrossRef] [PubMed]

65. Schauer, K.; Rodionov, D.A.; de Reuse, H. New substrates for TonB-dependent transport: Do we only see the "tip of the iceberg"? Trends Biochem. Sci. 2008, 33, 330-338. [CrossRef] [PubMed]

66. Desvaux, M.; Hébraud, M.; Talon, R.; Henderson, I.R. Secretion and subcellular localizations of bacterial proteins: A semantic awareness issue. Trends Microbiol. 2009, 17, 139-145. [CrossRef] [PubMed]

67. Palmer, T.; Berks, B.C. The twin-arginine translocation (Tat) protein export pathway. Nat. Rev. Microbiol. 2012, 10, 483-496. [CrossRef] [PubMed]

68. Méndez, J.; Fernández, L.; Menéndez, A.; Reimundo, P.; Pérez-Pascual, D.; Navais, R.; Guijarro, J.A. A chromosomally located traHIJKCLMN operon encoding a putative type IV secretion system is involved in the virulence of Yersinia ruckeri. Appl. Environ. Microbiol. 2009, 75, 937-945. [CrossRef] [PubMed]

69. Voth, D.E.; Broederdorf, L.J.; Graham, J.G. Bacterial Type IV secretion systems: Versatile virulence machines. Future Microbiol. 2012, 7, 241-257. [CrossRef] [PubMed]

70. Ron, E.Z. Bacterial stress response. In The Prokaryotes; Springer: Berlin, Germany; Heidelberg, Germany, 2006; pp. 1012-1027.

71. Kazmierczak, M.J.; Wiedmann, M.; Boor, K.J. Alternative sigma factors and their roles in bacterial virulence. Microbiol. Mol. Biol. Rev. 2005, 69, 527-543. [CrossRef] [PubMed]

72. Haugen, S.P.; Ross, W.; Gourse, R.L. Advances in bacterial promoter recognition and its control by factors that do not bind DNA. Nat. Rev. Microbiol. 2008, 6, 507-519. [CrossRef] [PubMed]

73. Storz, G.; Hengge, R. Bacterial Stress Responses; American Society for Microbiology Press: Washington, DC, USA, 2010.

74. Phadtare, S. Recent developments in bacterial cold-shock response. Curr. Issues Mol. Biol. 2004, 6, $125-136$. [PubMed]

75. Ermolenko, D.N.; Makhatadze, G.I. Bacterial cold-shock proteins. Cell. Mol. Life Sci. 2002, 59, $1902-1913$. [CrossRef] [PubMed]

76. Horn, G.; Hofweber, R.; Kremer, W.; Kalbitzer, H.R. Structure and function of bacterial cold shock proteins. Cell. Mol. Life Sci. 2007, 64, 1457-1470. [CrossRef] [PubMed]

77. Huvet, M.; Toni, T.; Sheng, X.; Thorne, T.; Jovanovic, G.; Engl, C.; Buck, M.; Pinney, J.W.; Stumpf, M. The evolution of the phage shock protein response system: Interplay between protein function, genomic organization, and system function. Mol. Biol. Evol. 2011, 28, 1141-1155. [CrossRef] [PubMed]

78. Laub, M.T.; Goulian, M. Specificity in two-component signal transduction pathways. Annu. Rev. Genet. 2007, 41, 121-145. [CrossRef] [PubMed] 
79. Mika, F.; Hengge, R. A two-component phosphotransfer network involving ArcB, ArcA, and RssB coordinates synthesis and proteolysis of oS (RpoS) in E coli. Gene Dev. 2005, 19, 2770-2781. [CrossRef] [PubMed]

80. Saier, M.H.; Wentzel, D.L.; Feucht, B.U.; Judice, J.J. A transport system for phosphoenolpyruvate, 2-phosphoglycerate, and 3-phosphoglycerate in Salmonella typhimurium. J. Biol. Chem. 1975, 250, 5089-5096. [PubMed]

81. Delcher, A.L.; Bratke, K.A.; Powers, E.C.; Salzberg, S.L. Identifying bacterial genes and endosymbiont DNA with Glimmer. Bioinformatics 2007, 23, 673-679. [CrossRef] [PubMed]

82. Lowe, T.M.; Eddy, S.R. tRNAscan-SE: A program for improved detection of transfer RNA genes in genomic sequence. Nucleic Acids Res. 1997, 25, 955-964. [CrossRef] [PubMed]

83. Lagesen, K.; Hallin, P.; Rødland, E.A.; Stærfeldt, H.; Rognes, T.; Ussery, D.W. RNAmmer: Consistent and rapid annotation of ribosomal RNA genes. Nucleic Acids Res. 2007, 35, 3100-3108. [CrossRef] [PubMed]

84. Aziz, R.K.; Bartels, D.; Best, A.A.; DeJongh, M.; Disz, T.; Edwards, R.A.; Formsma, K.; Gerdes, S.; Glass, E.M.; Kubal, M. The RAST Server: Rapid annotations using subsystems technology. BMC Genom. 2008, 9, 75. [CrossRef] [PubMed]

85. Tamura, K.; Stecher, G.; Peterson, D.; Filipski, A.; Kumar, S. MEGA6: Molecular evolutionary genetics analysis version 6.0. Mol. Biol. Evol. 2013, 30, 2725-2729. [CrossRef] [PubMed]

(C) 2016 by the authors; licensee MDPI, Basel, Switzerland. This article is an open access article distributed under the terms and conditions of the Creative Commons Attribution (CC-BY) license (http://creativecommons.org/licenses/by/4.0/). 